\title{
CULTURAL TRANSFER AS A FIELD FOR THE OBSERVATION OF HISTORICAL CULTURAL STUDIES. THE EXAMPLE OF THE RUSSIAN EMPIRE*
}

The article focuses on the concept of cultural transfer not as a historical method per se, but as a field of historical observation. Referring to the examples of individuals, networks and urban milieus, the author discusses the possibilities to highlight the practices of transfer between the Russian Empire and Western Europe, but also within the Russian Empire. It is argued that studies on cultural transfer may firstly fill an important gap between microleveled and macro-leveled approaches. The observation of transfer processes is also a prerequisite for historical comparison. Thus, studying processes and practices of transfers leads to a broader understanding of how culture and society of the Russian Empire functioned.

Ke y w o rd s: Cultural history; cultural transfer; historical cultural studies; Russian history.

Статья рассматривает явление культурного трансфера не как собственно исторический метод, но как поле исторического наблюдения. На примере отдельных людей и их групп, а также разных типов городской среды изучаются возможности трансфера между Российской империей и Западной Европой, а также внутри Российской империи. Утверждается, во-первых, что изучение культурного трансфера может стать важным звеном между микро- и макроподходами в историческом исследовании. Кроме того, наблюдение над процессами трансфера является необходимым условием для исторического сравнения. Таким образом, изучение процессов и практики трансфера ведет к более глубокому пониманию того, как функционировали культура и общество в Российской империи.

Ключевы е слова: история культуры; культурный трансфер; историко-культурные исследования; российская история.

* This essay was first given as a talk at the Higher School of Economics, Moscow, in March 2012 and was slightly revised as a result of the instructive discussions with my colleagues there. Translated from German by John Deasy, Mainz. 
I. Cultural history, cultural transfer and Russia

The "cultural turn" has moved into East European History with a vengeance already for some time. "Culture", understood here as the whole of human motivations and actions, was certainly already a subject of interest beforehand, but cultural history has created a theoretical concept and methods of proceeding which make it possible to come closer to the reconstruction of historical lifeworlds by disclosing one's own prior assumptions. In this connection, the finding has become generally accepted that historical lifeworlds of individuals, smaller groups and larger groups are not static, but exposed to influences, changes and translations [Vierhaus; Daniel].

As also in other fields of cultural scientific historiography, research with regard to Eastern Europe is interested in "symbols", "rituals" and "communication". Symbols, as reflexive signs, form the communication situations; symbols, which include artefacts as well as actions, shape communication [Lindner; Bonnell, Hunt]. The interpreting and reading of symbols and the establishment of communication, whether in the sense of the actors' intention or not, lead to the exchange of information and to transfer. Here in the following paper it is not intended to direct our look at processes which have recently been examined in very detailed structured, in part micro historical case studies [Sperling; Pietrow-Ennker].

It is intended rather to be an outline of the problem of the question of what relevance is attached to access to cultural transfer in the light of the cultural turn: Long before the "discovery" of transnational history and its "siblings", interwoven history and histoire croisée, it was very clear to many historians of Eastern Europe that one cannot describe the history of this area in any other way, admittedly without this finding as such then being classified in concepts which had a paradigmatic quality [Osterhammel; Patel; Conrad; Renner; Werner, Zimmermann, 2002; 2006].

Such a discussion for Russia does not only lead into the early $18^{\text {th }}$ century, when Peter the Great made a comparison with the western and northern neighbours and, under the conditions of the Great Northern War, prescribed a phase of modernisation for his country, the consequences of which proved to be extremely ambivalent for the state and the subjects. Russia was simply not a "white sheet of paper", as Leibniz wrote to Peter [Groh, S. 41-53]. It was not a construct lacking tradition without outside links, whose character and people let themselves be formed ad hoc with the faith in progress of a rational-technicised enlightenment.

Peter the Great tried by practical policy and a new form of presentation of power, in which the assumption of the title of Imperator in 1722 was just one piece of a jigsaw, to control a discourse which had basically been conducted already since the days of the rising Muscovite realm with varying intensity and different concepts, and which had experienced a first climax in the days of Ivan Grozny in the $16^{\text {th }}$ century. Ivan, who left his country wrecked by terror and war, did not shrink from emphasising the value, indeed the superiority of his own denomination, his own system 
of rule, and social and societal state, the shape of which in the tsardom was marked to a particularly high extent by the ruler's plenitude of power, worn outwardly perhaps more than actually existing, against papal legates and Bohemian Brethren, against the English queen or the Polish king [Nitsche]. The discourse, which began there, was one about differentiation and opening, exclusion and inclusion - especially then in the $17^{\text {th }}$ century, in which xenophobia and increased contacts with "foreigners" became two sides of a medal [Scheidegger; Poe].

But the process of a mutual cultural transfer is always also to be observed in the communicative actions, that became tangible already before the $18^{\text {th }}$ century, but with the $18^{\text {th }}$ century it can be described as a constantly expanding cultural transfer between the elites [Доронин]. The interconnections coming into being in the transfer were a permanent reciprocal discovery that in turn led to a change in the respective cultural sphere, to an Internalising of certain practices, institutions, knowledge and views of the world. This was not a one-way street, as is suggested from time to time by trends in research, insisting for all too long on "the Germans in the East" and contributing deliberately or unintentionally to the disastrous consequences in the $20^{\text {th }}$ century. These trends are experiencing, it is true, a certain, not unproblematic renaissance in Russia itself recently at conferences with general topics, such as "The Germans' contribution in Russia", but as research strategy stopgap solutions they merely examine the difficult change of paradigms in Russian historical science which is taking place closely dovetailed with the patriotically shaped history policies [Bohn; Simon]. Such one-way street perspectives have, though, been on the retreat for a long time in Germany. The look at all the historical actors involved is sought in a much more differentiated manner. Further research works suggest themselves here. They could be subsumed under the term "cultural transfer" that has been adopted, but has to be explained in more detail, which one should perhaps better put more precisely as "intercultural transfer" or using the English term "cultural exchange", because it implies the look at reciprocity and is more open for the hybridisation occurring in the process [Kaelble, Schriewer]. To observe this transfer, which results in an open-ended, albeit in the medium term recognisable change in certain individuals and groups in their environment, is a field of observation which can be located, on the one hand, between the results of historical social science - represented by Dietrich Geyer and Manfred Hildermeier for a while for East European history in Germany - which was first and foremost concerned with the shaping strength of structures, in particular those of a socio-economic kind, and, on the other hand, the trends in new cultural historiography, mentioned at the beginning, which are moving the individual in his life world, his cultural environment, back into the focus of attention again and thus, as Jörg Baberowski puts it, "seek to understand the life of historical man in his cultural constraint" [Baberowski, 2001, S. 17].

In order to be able to extract, understand and classify structures, historical social science lived under the more or less openly revealed application 
of modified modernisation theories of comparison. Manfred Hildermeier named the limited possibilities of this concept when he examined the history of Alexander Gerschenkron's backwardness model, according to which Russian history had the opportunity to quickly catch up on the "West" that served as a point of comparison, however it might be understood, for its heuristic value. Not a few representatives of the Russian elite regarded a backwardness they already felt in their time as an opportunity, because it would give a future Russian development the opportunity to avoid mistakes [Hildermeier, 1987; Kusber, 2013].

In the review by historians in the $20^{\text {th }}$ century, the history of prerevolutionary Russia could only be shown negatively in the balance sheet through comparison, especially since, viewed from its result, it ended inadictatorship whichelevatedeconomicmodernisation tobetheprogramme at the expense of the individual and thus failed terribly. Hildermeier therefore spoke in favour of a social history taking account of the structures in the cultural expansion which was intended to remedy the coarsening and apodictic assessment. Jörg Baberowski, on the other hand, rejected a prior analysis of structures as outdated, and demands a small scale and chronologically restricted study, whereby in his own works he attempts, it is true, in his interpretation of Michel Foucault, "to make [the individual] speak", but at the same time he starts from the persistency of the cultural environment and implicitly, as the modernisation theoreticians also did, makes a comparison again and again [Baberowski, 2003, S. 17-53; Hildermeier, 2004].

Now a human being is constantly comparing in his activity - that may be considered to be a basic continuous anthropological factor and in the scientific sector, too, the pronounced and unadmitted comparison shapes his perception to a large extent, perhaps even his interest in knowledge. However, it always has to be examined how perception, assessment and analysis are linked together and for what ultimate purpose this is done. To come back to Ivan Grozny and Peter I as historic examples: The famous correspondence between Ivan Grozny and his former commander and adviser, Prince Andrej Kurbski, who had fled into exile in Poland-Lithuania for fear of an impending fall from favour, is, whether one regards it as a forgery of the $17^{\text {th }}$ century or not, an argumentative clash over the forms and exercise of rule, as well as a religious conception of oneself, that lives from comparisons and contrasts [Переписка Ивана Грозного...; Филюшкин]. And Peter I soberly compared the urban life, army and fleet, as he had observed them on his 'Great Embassy' to Holland and England in 1697/89, and noted the backwardness at home. Put in exaggerated terms, he compared Moscow with Amsterdam and London and tried to give his towns a new form, or even to found new ones, without adopting the content of West European urbanity. It did not play any role in his comparative operation which was directed towards the state's benefit. But what Peter I ordered on the basis of this, what he wanted to push forward through the recruitment of foreign experts and scholars, the dispatch of young sons of noble rank, was a cultural transfer, to return to this term again 
with the aim of modernisation which was initiated by the comparison of what he had inspected [Hughes, 1998, p. 22-26].

The historian, who tries his hand at comparisons, must, of course, select his objects of comparison in such a way that a certain validity will be attributed to the comparison operation, because, unlike the politician acting, he does not want to change the objects of comparison, but to describe them. But if he at the same time tends, as modernisation theoreticians for instance did, to take the objects of comparison all too stiffly or to construct them, as it were, anew again and again through the comparison, he thus robs them of their meaningfulness. The modernisation theoreticians all too often set out to search for what was in common or what differentiated, and selected the basis for their analysis, that is to say their sources, accordingly. The real interconnections, dependences and reciprocities thus remained out of consideration. A look at processes of cultural transfer can help to examine the objects of comparison again and again, because it is able to describe the way between both.

The somewhat blurred tertium comparationis of "the West" or "Europe", which has itself changed again and again in the course of Russia's modern history, and the Russian Imperium are not sufficient as objects of comparison, although this comparison has been sought again and again in the historical discourse, without stating whether one has political entities, religious or denominational common bonds, the so-called "civil society", or other attributions in mind. One may think of Feodor Tyutčev's declaration in 1848 that at that time he only saw two political principles "Russia and the Revolution", by which he meant the contrast between stability and order in Russia and chaos and decline in Europe. But an exact definition of what one wants to understand by "Europe" each time is just as necessary as a reflection about what one wants to understand by "Russia", or as has been happening ever more often recently, by "Imperium" [Lieven; Миллер; Miller, Rieber; Герасимов и др.; Hosking; Burbank, Hagen, Remnev; Gerasimov, Semyonov; Kusber; Ауст, Вульпиус, Миллер]. In both cases it is the reconstruction of how the contemporaries in different social and societal contexts, the interested groups of actors in each case, understood their tertium comparationis in order to adjust it to the definition accepted heuristically for the scientific analysis. The questions stated here at the beginning of a transfer between Russia and the West belong now to the quite great topics of European history. Their relation to the present for the research context of the time is evident, which is why further differentiation is necessary.

If one now follows Johannes Paulmann, who has dealt with cultural transfer for Anglo-French history of the $19^{\text {th }}$ century, it is first necessary to define which two unities of action are intended to be examined with regard to the transfer. These do not have to be, Paulmann says, states or nations, they can also be religious communities or economic units. If this has been done, it is possible to delimit in the transfer process which cultural term it is worthwhile applying [Paulmann]. With a look at modern Russian 
history, I would further expand these proposals and consider an analysis of the cultural transfer between the various functional elites of different countries and societies to be just as fruitful as the study of the transfer within the tsarist realm, for instance from functional elites to the broad mass of the population, the urban, but above all the peasant sections.

Here firstly the ways of transfer should be studied, thus who or which group of persons made use of a certain way of transfer and why. Because not always can one quote prevailing political conditions, as in the case of Peter the Great, as a model for explaining why he sent a first delegation of students to Königsberg and not to the area under Polish-Lithuanian rule. It is necessary to pay attention why, at certain times, some things are not accepted, because they were considered to be uninteresting or unsuitable. Such occurrences can, of course, be observed at the highest level of state and within certain groups of the functional elite very much better than in the case of a transfer process between a functional elite and various groups of the population.

It is obvious why Catharine II in her "Great instruction" of 1767, in which she was formulating the goal rather than making an observation, said "Russia is a European power" [Schlözer] proceeded selectively in her rendering of the gleanings of her readings of enlightened authors, in order to impart her interpretation of enlightened thought to a few hundred deputies to the law code commission from the nobility, merchants, state peasants and the civil service and nationalities whom she summoned to Moscow in the same year [Чечулин].

On account of the lack of source material we can no longer reconstruct what impression of this law code commission small merchants, state peasants and single homestead servitors ("odnodvorci"), as well as the nationalities took with them to their often far distant homes. It constituted a new form of representation of power and was intended to announce the intention that the monarch was, it is true, determined to rule absolutely, however, she would be prepared to feel bound to a legal basis. We know too little about whether the form of the debates, in which many a noble estate owner would be called harshly to order by the presiding General Bibikov for interrupting a small craftsman from his gouvernement, left an impression lasting beyond that day [Kusber, 2008b, S. 364-369].

The position is generally very much better concerning the source material with regard to a cultural transfer between the functional elite and the "common people" from the mid-19" century on. Let us here take the example of soldiers with the introduction of general compulsory military service which, according to the will of the enlightened-bureaucratic reformers, was intended to transform the army into a kind of school of the nation. Werner Benecke recently reviewed what ideas one wanted to give the peasant soldiers of a (state) communal life within the course of several years of service to take home with them [Benecke, 2002; 2006]. After returning to their village, they were then intended to act as multipliers and propagandists of education. So a so-called "copeck literature" was 
specially prepared for the soldiers which was intended to present in an entertaining, to exaggerate one might say Readers Digest form, humanity, hygiene, observation of religious holidays, respect of ethnic minorities and religious communities among themselves, who for the most part would do their duty together. This genre made allowances for the fact that the soldiers' ability to read was poor and at the same time it was intended to help impart basic skills. It took into account that the soldier, perhaps torn out of the surroundings of his village for the first time, had to cope with a whole host of new impressions and to incorporate them into his lifeworld. All too often and sometimes hastily it has been stated that such endeavours for transfer remained unsuccessful precisely between the functional elites and common people. Jörg Baberowski spoke in a just as catchy as problematic metaphor from a "Dialogue between two doves".

First of all, he disregards the time factor in his verdict for prerevolutionary Russia, for transfer processes are always to be considered in a longue durée. Already in 1706, thus at the beginning of the reforms in the field of education, Professor Stieff in Breslau wrote perceptively about Peter the Great's first civil technical schools: "The cultivation of a whole nation is not the work of one year, but it probably often lasts a whole century before the arts are really established and got going" [Stiess, S. 167]. This observation should also be taken into account for the transfer processes in the second half of the $19^{\text {th }}$ century when what had been achieved in transfer processes in the functional elite formed by the nobility and civil servants was to be passed on to further circles of the population as a consequence of the great reform impetus under Alexander II [Кусбер].

Secondly, if one starts out from a "Dialogue between doves", the fact is overlooked that in the primary acquisition process a reshaping takes place of what is acquired. A selection takes place of what is worth knowing, communication channels and problems of understanding, previous knowledge and prejudices determine the result, which does not, however, mean that no exchange takes place. What the peasant soldiers learned only developed its effectiveness in the medium term and by no means in the way which the military reformers of the 1870 s had intended. The first Russian Revolution saw an extremely violent peasant protest in the summers of 1905 and 1906. In central Russia and elsewhere, the peasants utilised the decline in power of the state in order to take possession of what, according to traditional legal opinion, they were entitled to anyway. They drove cattle off estate meadows, did not perform the contractually agreed work and in many gouvernements they set estate owners' houses on fire extensively. Leo Trotsky, in his history of the 1905 Revolution, came to the conclusion that the peasants were hopelessly backward and, above all, by no means capable of learning, stuck to tradition and prevented any progress [Trotzki, S. 48; Engel]. This opinion is shared by many historians and was certainly also correct for many of the peasants in predominantly agrarian Russia. But, here too, the transfer of knowledge and education showed the way to change [Burbank]. Already Trotsky kept quiet 
in the interest of his way into the revolution about the fact that the peasants did not only refuse in many cases to let themselves be agitated by revolutionary activists in the countryside, but were already formulating their aims and ideas themselves in the first peasant union. In 1906 and 1907, the "Free Economic Society", a learned society, which had set itself the goal of the improvement of agriculture in the spirit of the Enlightenment since the age of Catharine the Great, sent correspondents out into the countryside to look into the reasons and the moving forces for the peasant protests. These correspondents, all of them members of the left-wing liberal intelligentsia, found that a large percentage were former soldiers, who with their increased knowledge of reading and writing, but in particular also with their experience of the wider world, going beyond the peasant world in miniature, the "mir", as the village community was called, put the peasants' wishes into appropriate language and set them down in writing [Kusber, 1997, S. 260-268].

Rural society, this is not a Russian peculiarity, was certainly marked by greater obstinacy than the urban centres, of which there were not admittedly all too many in the tsarist realm. With the Janus-faced educational process, which the peasant soldiers went through in their military service, the moving forces and the social subsystems bearing the cultural transfer have already been identified, in the course of which multiple encoding of personal and collective identities was able to take place.

These are (1) individual persons, (2) networks and (3) the urban areas in which these networks move.

II. Fields of observation

(1) About the persons: It is certainly a just as popular as wrong idea that a transfer of ideas and cultural techniques began suddenly under Peter the Great. Since the time of Ivan III towards the end of the $15^{\text {th }}$ century, foreign specialists - Greek diplomats, Italian architects, German physicians and others - had come into the country whose importance for the expansion of the Muscovite realm and for representation of rule turned into stone is clearly to be seen in the still recognisable shape of the Moscow Kremlin today, the further influence of which on the life worlds of the elite has admittedly remained limited [Ostrowski, p. $232 \mathrm{f}$.]

In the long term and in the struggle with increasing involvement of the Muscovite realm in the political relations of the Central and West European world of states, this transfer began, leading to an intensive self-reflection and accompanied by the acceptance of certain views, ideas and techniques. The reception of humanist cultural heritage via Kiev in the Polish-Lithuanian variant, but on the basis of Latinity, the dispute about the right belief, which led to the schism through the return to its "Greek roots", promoted this reflection [Okenfuss; Michels]. Cultivated statesmen, such as Afanasij Ordin-Naščokin, read cameralistic and constitutional literature of the $17^{\text {th }}$ century and tried to give it effect in administration and trade. Reflecting on the consequences led the open-minded Naščokin to an ambivalent conclusion. Towards the end of his life he had himself 
tonsured as a monk in 1672, observing: “...what concern are other nations' clothes to us. Their clothes will suit us just as little as ours do them.”

Peter the Great tried to accelerate the process that had begun virtually violently when he sent the nobles' sons to Germany, France, England and other countries for still mainly military training. However, around the mid $-18^{\text {th }}$ century, members of the elite began to travel of their own accord, once again with a medium-term effect, precisely not just on a diplomatic mission, but in order to go on a grand tour, and/or to educate themselves at the beginning of the $19^{\text {th }}$ century even as regular students at German reform universities. Not for nothing at the beginning of the 19th century did one speak of the "Göttingen soul" of the University of Moscow [Андреев, 2000; 2005]. The later polymath Michail Lomonosov in Marburg, the patron Ivan Betskoy in Paris, the later historiographer of the realm Nikolay Karamzin on a journey in Germany or the later minister of education Sergey Uvarov in Vienna - they all, who have been named here pars pro toto, were involved in quite different segments of the cultural transfer as multipliers.

Michail Lomonosov, since 1745 the first Russian member of the Academy of Sciences, worked as a versatile scholar [Heller; Schierle, 2005/2006] as a non-aristocratic homo novus in his disputes with other, mainly German members of the Academy about scientific questions, but also in the power struggles within the Academy, he sought the distinction with a national trait which prepared the ground the formation of a nation of Russians started later at the beginning of the 19th century which Nikolay Karamzin, who had been appointed imperial historiographer in 1803, sought to push forward with his glorification of autocracy and a statecentred consideration of Russian history [Karamzin; Black], while Sergey Uvarov intended to make this formation of a nation permanent in 1833 with the famed triad "Autocracy, Orthodoxy, Narodnost" referring to the ruler [Whittaker; Шевченко; Зорин].

Their journeys through life, which were initially marked by an enthusiastic reception for what they had absorbed in new ideas, lifeworlds and techniques abroad, but then, in confrontation with the lifeworld of their country of origin, they only adopted what seemed "useful" to them for the progress of their work, in Karamzin's and Uvarov's case therefore as "harmless" for the Russians, were able to show fundamental features of cultural transfer.

In this process, there is always a "preserving", forgetting and cutting out of information. A later use becomes possible under changed conditions, the change in use and lending of a new importance is also of significance for the openness and "success" of cultural transfer. Lomonosov, Karamzin and Uvarov were clearly shaped by these mechanisms in their biographies.

If the conscious or unconscious check of compatibility did not take place in the transfer process, this can mean the failure of the cultural transfer. The aforementioned Ivan Betskoy, who was the "ideal" representative of European Enlightenment of the French type in Catharine II's epoch, may serve as an example of this. He knew the encyclopedists personally through 
his long stays abroad and in the first decade of Catherine's reign he was her "Chief adviser" in educational policy. He was indeed convinced that it could be possible forthwith to create the type of new human being, who was no longer noble by birth, but just noble by education and training. He tried to put his avant-garde, reform educational concepts borrowed from Rousseau and others to the test in Russian reality, utilised orphanages and homes for foundlings founded by him in Moscow and Saint Petersburg as experimental fields and failed in this at the expense of the lives of many of the children in his care in a terrible manner, although guided by the best ideals [Kusber, 2008a, p. 134-146; Ерошкина].

(2) All the persons presented as moving forces in the transfer process passed on their information in networks, thus experiencing supraindividual efficacy. Therefore network analyses are to be examined to observe the cultural transfer. A special significance was attached to networks of a formal and informal kind in early modern Russia, leading at first through the ruler, with an increasing widening of the transfer within the elites, but also beyond them.

Other networks, which were spun in salons and literary societies, were more important for a multiplication of "transfer material" and which, despite their often cursory composition, are hardly to be underestimated in their significance as a catalyst for impetus. Little work has been done on examining Ivan Betskoy's household that may already be described as an early salon in which Lomonosov, the poet Gavriil Derzhavin and others met. The Freemason circles, which were established as products of the reception of the Enlightenment in the second half of the $18^{\text {th }}$ century and which even the heir to the throne and later short-reigning Tsar Paul sympathised with for a time, have been examined better, recently, for instance by Douglas Smith [Smith, 1999]. Rationality, philanthropic action and the effect on society were the propagated values. In the salons and literary associations, which were formed in the first quarter of the $19^{\text {th }}$ century, in a combination of early Romanticism and the Enlightenment and, in view of the political challenge by Napoleon, it was already very directly a matter of "Russia's place in Europe" [Sach]. In this connection, the committed writers and publicists from the milieus of the capital, and in most cases aristocrats, only rarely took a look at a target group going beyond the narrower reference frame. The "Lovers of the Russian word" on the one hand and the Arzamas circle on the other, for instance, were only aware of the peasants in the tsarist empire as a projection surface for their concepts [Martin]. Something similar applies for the loose groups in which the later Decembrists met in the period around 1825 and which were striving to proceed from determining positions to political action against the autocracy, and as a consequence were to fail in December 1825 at Senate Square in the capital Saint Petersburg.

Saint Petersburg with its assumed forms of social understanding - here too the state stood at the beginning with the assemblies decreed by Peter I [Hughes, 2002, p. 131-133] - showed already earlier and more 
comprehensively than Moscow forms of an "encounter" or assembly public which Martin Schulze-Wessel has also determined in the countryside for the mid- $19^{\text {th }}$ century [Schulze-Wessel]. In the process of cultural transfer, the different forms of expression of a public that had emerged through "Europeanisation", associations and competing periodicals, such as "Vestnik Evropy" and "Russki Vestnik" refer to the progressive replacement of the state's initiative at the beginning of the $19^{\text {th }}$ century, indeed in many cases a "counter-public" can already be determined here that has occasionally been used synonymously with the term obščestvo (= society) [Schierle, 2007]. The more the state regarded this counter-public with suspicion, the more it strove to select the cultural transfer, the more it could branch out and even be pushed into illegality in the reception. One example is the small but powerfully effective revolutionary movement in the $19^{\text {th }}$ century which found its way in its reception of German idealistic philosophy as well as of early French socialists through specific modifications to the path of individual terror that is probably particularly marked in Russia.

(3) In order to follow these networks from a micro and macro perspective, urban areas in particular seem to me to be interesting for cultural area research which already from their genesis were designed as transitional areas in which the productive exchange between dynamic and hybrid cultures could take place. St. Petersburg, but also Odessa, founded by the Black Sea in 1794, the capital of what was called New Russia, would provide suitable fields for examination.

Both cities as new foundations of the absolutist state should represent a new form of culture for themselves. To stay with Petersburg: Astonishingly enough the city has been little studied with regard to the question how far did civil society come in Russia which came into being where it formed itself in the urban area as the result of such transfer processes, in contrast to many provincial towns. This may be due to the superior strength of central state institutions and the court, the closeness of the state or the fact that the city was considered to be an "alien" solitaire in the Russian Empire, thus quite satisfying contemporary as well as later auto and hetero stereotypes [Custine; Zitiert nach: Stürickow]. However, Saint Petersburg, founded in 1703, is especially suitable for cultural transfer research. The city was after all, in the words of the Italian traveller Francesco Algarotti from the year 1739, intended to be the "Window to Europe", thus, to clothe it in our language, to be committed to a state-initiated cultural transfer. Indeed, Peter the Great's creation must be imagined with regard to such a function in both directions at the same time: Certainly one looked out from Saint Petersburg in many different respects towards Europe, but it fulfilled a further, at least just as important task. It was intended to be at the same time a shop-window for Europe within the Russian Empire [my argument in: Kusber, 2009]. It thus always has to be asked how forms of cultural transfer came into the capital and out of the capital into the empire. Already soon a Europeanising elite came into being in prerevolutionary Saint Petersburg, which at the beginning was drawn into the city on the northern periphery 
of the empire by Peter by force, by his successors in the $18^{\text {th }}$ century by the necessary service, but also the attraction of the court. Even when the official duty of the nobility was abolished, the court remained important in Saint Petersburg, not only on account of the closeness of the ruler, but also because the city's central administrative authorities and military institutions promised possibilities of promotion and the intercession of influential protectors who had already made their way. This led to a concentration of elites in the city on the Neva which had nothing like it in the Russian Empire.

In addition, there was a "non-Russian" elite, whose representatives occupied outstanding social positions in the administration, military, but also trade and commerce. These members of non-Russian elites had come under the rule of the Tsars through the expansion of the empire. Baltic Germans should be mentioned here, for the Baltic Provinces gained under Peter were regarded among contemporaries as a "Reservoir of competent human beings", and these territories lay, so to speak, before the gates of the capital [Scharf, S. 167-180]. But also Poles, Armenians, Georgians, Fins, finally also Jews streamed into the capital, with quite different possibilities of participation in the elites. Finally there were also immigrants from abroad who were trying to make their fortune in the capital and port city and who in the $18^{\text {th }}$ and also $19^{\text {th }}$ centuries put their hope in the need for specialised workers as well as on the aura of their West European origin which could often not keep up with their actual capabilities. Saint Petersburg's elites represented, to the extent which the city on the Neva grew, a "melting pot" in which the traditional elites did, it is true, take the leading position and membership of the elites remained reserved for the nobility, with exceptions, until far into the $19^{\text {th }}$ century [Шангина]. But the intercultural overlapping areas in the urban area - this can apply just as much for instance for Odessa - despite all the delimitation carried out, offered the possibility of learning reciprocally from each other. Cultural transfer then led in the best sense to cultural transformation [from the perspective of cultural history: Sylvester; Hausmann]. This process from transfer to cultural transformation can be regarded as concluded, if the acquired, originally foreign knowledge or information is included in argumentation or action contexts of one's own life, the foreign origin is in part no longer recognisable, or even deliberately concealed. The reflection on own and outside perception does not necessarily take place in this connection, however stereotypes are always involved in steering what is perceived and transferred in networks or in greater contexts. In this connection, it turns out for the example Saint Petersburg that the process only led to a partial transformation of the elites. In this sense, in certain fields the city was the fascinating "Laboratory of the modern age", as it was described by Karl Schlögel, and at the same time the scene of contested transfer processes [Schlögel]. Particularly in the urban area, parts of the elite of the tsarist empire tried to break up the framework which the state gave for transfer, only all too often reduced to technical and economic knowledge and which was now felt to be a fetter. Nowhere does this become more 
perceptible than in Saint Petersburg. While processing constitutional concepts in 1825, the Decembrists attempted a rebellion at Senate Square, while processing revolutionary concepts in 1881, the assassination of Tsar Alexander II by the Catharine Canal succeeded [Brower; Ковальчук, с. 245262]. The fact that in many respects the state proved incapable of reacting to the further development of the successfully Europeanised and now really European elite, and that it should have amended the social constitution in an accelerated and steered manner for a comprehensive cultural transfer in the whole empire, proved to be a burden. This can not only be seen from the peasant and nationalities disturbances in 1905, but above all from the disintegration of the regime in February 1917 which neither peasants, workers nor urban elites were prepared to follow any further.

\section{Conclusion}

Research into processes of cultural transfer are certainly not capable of serving to provide earth-shattering explanation approaches for world wars and the rise of totalitarian regimes, but precisely for East European history they can provide explanation approaches and throw a differentiated light on certain historical phenomena, which cannot be explained with a look at the great socio-economic structures but also with the description of very small and individual life-worlds, which can lead to the ascertainment of an incomparable own time of each phenomenon and each state entity. Cultural transfer research may supply some connecting links for this. In this connection, cultural transfer is not, this should be emphasised in conclusion, a method, just as an entwined history is also not really a method. But the processes under discussion at the different levels of varying range presented here can be revealed with the help of cultural historical procedures, are able to illuminate the lifeworld dimension in an additional way, and from there a comparative perspective also becomes possible. This is true certainly not just for Russia and Eastern Europe.

\footnotetext{
Андреев А. Ю. Московский университет в общественной жизни России начала XIX века. М., 2000.

Андреев А. Ю. Русские студенты в немецких университетах XVIII - первой половины XIX века. М., 2005.

Ауст, Вульпиус, Миллер - Imperium inter Pares, Роль трансферов в истории Российской империи (1700-1917) : сб. ст. / ред. М. Ауст, Р. Вульпиус, А. Миллер. М. : Нов. лит. обозрение, 2010.

Герасимов и др. - Новая имперская история постсоветского пространства / ред. И. В. Герасимов, С. В. Глебов, А. П. Каплуновский и др. Казань, 2004.

Доронин - Вводя нравы и обычаи Европейские в Европейском народе: к проблеме адаптации западных идей и практик в Российской империи / ред. А. В. Доронин. M., 2008.

Ерошкина А. Н. Администратор от культуры (И. И. Бецкой) // Русская культура последней трети XVIII века - времени Екатерины второй / под ред. Л. Н. Пушкаревой. 1997. С. 71-90.

Зорин А. Л. Сергей Семенович Уваров. Идеология «Православие - самодержавие народность» и ее немецкие источники // В раздумьях о России (XIX в.) / ред. Е. Л. Радынская. М., 1996. С. 105-128.
} 

2003.

Ковальчук - Санкт-Петербург. 300 лет истории / ред. В. М. Ковальчук и др. СПб.,

Кусбер Я. Трансфер и сравнение: Университетские сообщества России и Германии // Сословие русских профессоров: Создатели статистов и смыслов / ред. Е. А. Вишленкова, И. М. Савельева. М., 2013. С. 191-211.

Миллер - Российская империя в сравнительной перспективе : сб. ст. / ред.

А. И. Миллер. М., 2004.

Переписка Ивана Грозного с Андреем Курбским. М., 1993.

Филюшкин А. И. Андрей Курбский. Молодая гвардия. М., 2008.

Чечулин - Наказ императрицы Екатерины II, данный комиссии по сочинению проекта нового уложения / ред. Н. Д. Чечулин. М., 1907. C. LII, LXXVII-LXX, CI, $\mathrm{CV}, \mathrm{CXX}$ f.

Шангина - Многонациональный Петербург. История. Религия. Народы / ред. И. И. Шангина и др. СПб., 2002.

Шевченко М. М. Сергей Семенович Уваров // Русские консерваторы / ред. М. М. Шевченко. М., 1997. С. $97-135$.

Baberowski J. Die Entdeckung des Unbekannten. Russland und das Ende Osteuropas // Geschichte ist immer Gegenwart. Vier Thesen zur Zeitgeschichte / ed. J. Baberowski. Stuttgart ; München, 2001. S. 9-42.

Baberowski J. Der Rote Terror. Die Geschichte des Stalinismus. München, 2003.

Benecke $W$. Kopekenliteratur für Russlands Wehrpflichtige. Die „Soldatskaja biblioteka 1896-1917“// Jahrbücher für Geschichte Osteuropas. 2002. 50. S. 246-275.

Benecke W. Militär, Reform und Gesellschaft im Zarenreich. Die Wehrpflicht in Russland 1874-1914. Paderborn, 2006.

Black J. L. Nicholas Karamzin and the Russian Society in the Nineteenth Century. A Study in Russian Political Thought. Toronto, 1975.

Bohn T. Paradigmawechsel in der russischen Historiographie? Sechs Thesen und drei Prognosen // Österreichische Osthefte. 2002. 44. S. 93-105.

Bonnell, Hunt - Beyond the Cultural Turn. New Directions in the Study of Society and Culture / ed. V. E. Bonnell, L. Hunt. Berkeley, 1999.

Brower D. Training the Nihilists. Education and Radicalism in Russia. Ithaca, 1975.

BurbankJ. Russian Peasants got to court. Legal culture in the country side, $1905-1917$. Bloomington; Indianapolis, 2004.

Burbank, Hagen, Remnev - Russian Empire. Space, People, Power, 1700-1930 / ed. J. Burbank, M. V. Hagen, A. Remnev. Bloomington ; Indianapolis, 2007.

Conrad, Osterhammel - Das Kaiserreich transnational. Deutschland in der Welt 18711914 / ed. S. Conrad, J. Osterhammel. Göttingen, 2004.

Custine A. de. Russische Schatten. Prophetische Briefe aus dem Jahre 1839. Nördlingen, 1985.

Daniel U. Kompendium Kulturgeschichte. Theorien, Praxis, Schlüsselwörter. Frankfurt a. M., 2001. S. 220f.

Empire Speaks out? Languages of Rationalization and Self-Description in the Russian Empire / ed. J. Kusber, I. Gerasimov, A. Semyonov. Leiden, 2009.

Engel B. Russian Peasant Views of City Life, 1861-1914// Russian Review. 1993. 52. P. $445-459$

Groh D. Russland im Blick Europas. 300 Jahre historische Perspektiven. 2. Aufl. Frankfurt, 1988.

Hausmann G. Universität und städtische Gesellschaft in Odessa: 1865-1917. Soziale und nationale Selbstorganisation an der Peripherie des Zarenreiches. Stuttgart, 1998.

Heller $W$. Kooperation oder Konfrontation. M. V. Lomonosov und die russische Wissenschaft im 18. Jahrhundert // Jahrbücher für Geschichte Osteuropas NF. 1990. 39. S. $1-24$.

Hildermeier M. Das Privileg der Rückständigkeit. Anmerkungen zum Wandel einer Interpretationsfigur der neueren russischen Geschichte // Historische Zeitschrift. 1987. 244. S. 557-603.

Hildermeier M. Traditionen der Aufklärung in der russischen Geschichte // Interdisziplinarität und Internationalität. Wege und Formen der Rezeption der französischen und der britischen Aufklärung in Deutschland und Russland im 18. Jahrhundert / Hrsg. H. Duchhardt, C. Scharf. Mainz, 2004. S. 1-16.

Hosking G. Russland, 1552-1917. Nation oder Imperium? 1552-1917. Berlin, 2000.

Hughes L. Russia in the Age of Peter the Great. New Haven, 1998. 
Hughes L. Peter the Great. A Biography. New Haven; London, 2002.

Karamzin N. M. Karamzin's Memoir on Ancient and Modern Russia / ed by R. Pipes. Cambridge, Mass., 1959.

Kusber J. Krieg und Revolution in Rußland 1904-1906. Das Militär im Verhältnis zu Wirtschaft, Autokratie und Gesellschaft. Stuttgart, 1997.

Kusber J. Individual, Subject and Empire: Toward a Discourse on Upbringing, Education and Schooling in the Time of Catherine II // Ab Imperio. 2008a. 2. S. 125-156.

Kusber J. Katharina II., das Russländische Imperium und die Bildung seiner Untertanen // Jahrbücher für Geschichte Osteuropas. 2008b. 56. S. 358-378.

Kusber J. Kleine Geschichte St. Petersburgs. Regensburg, 2009.

Kusber J. Die Kontinuität der Fremdheit. Russland als das andere in historischer Perspektive // Osteuropa. 2013. 63 (2-3). S. 257-268.

Lieven D. Empire. The Russian Empire and Its Rivals. London, 2000.

Lindner R. Im Reich der Zeichen // Osteuropäische Geschichte als Kulturgeschichte, Osteuropa. 2003. 12. S. 1757-1771.

Martin A., Romantics M. Reformers, Reactionaries. Russian Conservative Thought in the Reign of Alexander I. DeKalb, 1997.

Michels G. B. At War with the Church: Religious Dissent in Seventeenth-Century Russia. Stanford: Stanford Univ. Press, 1999. 2004.

Miller, Rieber - Imperial Rule / Hrsg. A. I. Miller, A. J. Rieber. Budapest ; New York,

Nitsche P. „Nicht an die Griechen glaube ich, sondern an Christus“. Russen und Griechen im Selbstverständnis des Moskauer Staates an der Schwelle zur Neuzeit. Düsseldorf, 1991.

Okenfuss M. J. The Rise and Fall of Latin Humanism in Early Modern Russia. Pagan Authors, Ukrainians, and the Resiliency of Muscovy. Leiden usw., 1995.

OsterhammelJ. Transnationale Gesellschaftsgeschichte: Erweiterung oderAlternative?// Geschichte und Gesellschaft. 2001. 27. S. 464-479.

Ostrowski D. The Growth of Muscovy // The Cambridge Historiy of Russia. Vol. I.

From Early Rus to 1689 / ed. P. Maureen. Cambridge, 2006. P. 213-239.

Patel K. K. Überlegungen zu einer transnationalen Geschichte. Berlin, 2004.

Paulmann J. Internationaler Vergleich und interkultureller Transfer. Zwei Forschungsansätze zur europäischen Geschichte des 18. bis 20. Jahrhundert // Historische Zeitschrift. 1998. 267. S. 649-685.

Pietrow-Ennker - Kultur in der Geschichte Russlands. Räume, Medien, Identitäten, Lebenswelten / ed. B. Pietrow-Ennker. Göttingen, 2007.

Poe M. T. A People Born to Slavery. Russia in Early Modern European Ethnography, 1476-1748. Ithaca etc., 2000.

Renner A. Die Erforschung der Langsamkeit. Russische Geschichte des 18. Jahrhunderts aus transnationaler Sicht // Archiv für Sozialgeschichte. 2002. 42. S. 297-314.

Sach M. ,...setzen Sie sich und erzählen Sie!” Russische Salonkultur und russische Salonnièren seit der Zeit Katharinas II. bis in die erste Hälfte des 19. Jahrhunderts // Historische Geschlechterforschung / hg. B. Lundt. Stuttgart, 2006. (= Historische Miteilungen der Ranke Gesellschaft, 19). S. 83-104.

Scharf C. Katharina II., Deutschland und die Deutschen. Mainz, 1995.

Scheidegger G. Perverses Abendland, barbarisches Russland. Begegnungen des 16. und 17. Jahrhunderts im Schatten kultureller Missverständnisse. Zürich, 1993.

Schierle I. "For the Benefit and Glory of the Fatherland": The Concept of Otechestvo // Eighteenth-Century Russia: Society, Culture, Economy. Papers from the VII International Conference of the Study Group on Eighteenth-Century Russia (Wittenberg 2004) / Hg. R. Bartlett, L.-C. Gabriela. Berlin, 2007. S. 283-295.

Schierle I. „Vom Nationalstolze“: Zur russischen Rezeption und Übersetzung der Nationalgeistdebatte im 18. Jahrhundert // Zeitschrift für slavische Philologie. 2005/2006. 64 (1). S. $63-85$.

Schlögel K. Jenseits des Großen Oktober. Das Laboratorium der Moderne, Petersburg 1909-1921. Berlin, 1988.

[Schlözer A. L., Übers.]. Katharinä der Zweiten Kaiserin und Gesetzgeberin von Rußland. Instruction für die zu Verfertigung des Entwurfs zu einem neuen Gesetzbuche verordnete Commission. Riga und Mitau, 1769 (Reprint Frankfurt a. M., 1970.

Schulze-Wessel M. Städtische und ländliche Öffentlichkeit in Rußland 1848 // Zeitschrift für Geschichtswissenschaft. 2000. 48 (4). S. 293-308. 
Simon G. Russland. Historische Selbstvergewisserung und historische Mythen. Geschichtsdeutungen im internationalen Vergleich. München, 2003. (= Zur Diskussion gestellt, 63). S. 61-74.

Smith D. Working the Rough Stone. Freemasonry and Society in Eighteenth Century Russia. DeKalb, 1999.

Sperling - Jenseits der Zarenmacht. Dimensionen des Politischen im Russischen Reich, 1800-1917 / ed. W. Sperling. Frankfurt a M. ; New York, 2008.

Stiess C. [Stieff]. Relationen von dem gegenwärtigen Zustand des moskowitischen Reichs. Frankfurt usw., 1706.

Stürickow R. Reisen nach St. Petersburg. Die Darstellung St. Petersburgs in Reisebeschreibungen (1815-1861). Frankfurt a. m., 1990. 2005 .

Sylvester R. P. Tales of old Odessa: crime and civility in a city of thieves. DeKalb, Ill.,

Trotzki L. Die russische Revolution 1905. Berlin, 1923.

Vergleich und Transfer. Komparatistik in den Sozial-, Geschichts- und Kulturwissenschaften / Hrsg. H. Kaelble, J. Schriewer. Frankfurt a. M. ; New York, 2003. S. 9-52.

Vierhaus R. Die Rekonstruktion historischer Lebenswelten. Probleme moderner Kulturgeschichtsschreibung // Wege zu einer neuen Kulturgeschichte / ed. L. Hartmut. Göttingen, 1995. S. 7-25.

Werner M., Zimmermann B. Vergleich, Transfer, Verflechtung. Der Ansatz der Histoire croisée und die Herausforderung des Transnationalen // Geschichte und Gesellschaft. 2002. 28. S. 607-636.

Werner M., Zimmermann B. Beyond Comparison. Histoire Croisée and the Challenge of Reflexivity // History and Theory. 2006. 45. S. 30-50.

Whittaker C. H. The Ideology of Sergei Uvarov: An Interpretive Essay // Russian Review. 1978. 37. P. 158-176.

Andreev, A. Yu. (2000). Moskovskij universitet v obshhestvennoj zhizni Rossii nachala $X I X$ veka [Moscow university in social life of Russia in the early $19^{\text {th }}$ century]. Moscow.

Andreev, A. Yu. (2005). Russkie studenty' $v$ nemeczkih universitetah XVII - pervoj poloviny' XIX veka [Russian students in German universities in $17^{\text {th }}-$ first half of the $19^{\text {th }}$ century]. Moscow.

Aust, M., Vulpius, R. \& Miller, A. (Eds.). (2010). Imperium inter Pares, Rol' transferov $v$ istorii Rossijskoj imperii (1700-1917): sb. st. [Imperium inter Pares, the role of transfer services in the history of the Russian Empire (1700-1917): collection of articles]. Moscow: Nov. lit. obozrenie.

Baberowski, J. (2001). Die Entdeckung des Unbekannten. Russland und das Ende Osteuropas. In Geschichte ist immer Gegenwart. Vier Thesen zur Zeitgeschichte (p. 9-42). Stuttgart, München.

Baberowski, J. (2003). Der Rote Terror. Die Geschichte des Stalinismus. München.

Benecke, W. (2002). Kopekenliteratur für Russlands Wehrpflichtige. Die ,Soldatskaja biblioteka 1896-1917“. Jahrbücher für Geschichte Osteuropas, 50, 246-275.

Benecke, W. (2006). Militär, Reform und Gesellschaft im Zarenreich. Die Wehrpflicht in Russland 1874-1914. Paderborn.

Black, J. L. (1975). Nicholas Karamzin and the Russian Society in the Nineteenth Century. A Study in Russian Political Thought. Toronto.

Bohn, T. (2002). Paradigmawechsel in der russischen Historiographie? Sechs Thesen und drei Prognosen. Österreichische Osthefte, 44, 93-105.

Bonnell, V. E. \& Hunt, L. (1999). Beyond the Cultural Turn. New Directions in the Study of Society and Culture. Berkeley.

Brower, D. (1975). Training the Nihilists. Education and Radicalism in Russia. Ithaca.

Burbank, J. (2004). Russian Peasants got to court. Legal culture in the country side, 1905-1917. Bloomington; Indianapolis.

Burbank, J., Hagen, M. V. \& Remnev, A. (2007). Russian Empire. Space, People, Power, 1700-1930. Bloomington; Indianapolis.

Chechulin, N. D. (Ed.). (1907). Nakaz imperatricy' Ekateriny' II, danny'j komissii po sochineniyu proekta novogo ulozheniya [Order of the empress Ekaterina II, given to the committee for making the project of the new code] (p. LII, LXXVII-LXX, CI, CV, CXX f). Moscow. 
Conrad, S. \& Osterhammel, J. (Eds.). (2004). Das Kaiserreich transnational. Deutschland in der Welt 1871-1914. Göttingen.

Custine, A. de. (1985). Russische Schatten. Prophetische Briefe aus dem Jahre 1839. Nördlingen.

Daniel, U. (2001). Kompendium Kulturgeschichte. Theorien, Praxis, Schlüsselwörter. Frankfurt a. M.

Doronin, A. V. (Ed.). (2008). Vvodya nravy' i oby'chai Evropejskie v Evropejskom narode: $k$ probleme adaptacii zapadny'h idej i praktik v Rossijskoj imperii [Introducing European manners and customs to Europe people: studying the problem of adaptation of western ideas and practices in the Russian Empire]. Moscow.

Engel, B. (1993). Russian Peasant Views of City Life, 1861-1914. Russian Review, 52, 445-459.

Eroshkina, A. N. (1997). Administrator ot kul'tury' (I. I. Beczkoj) [Administrator from culture (I. I. Betskoi)]. In L. N. Pushkareva (Ed.). Russkaya kul'tura poslednej treti $X V I I I$ veka - vremeni Ekateriny' vtoroj [Russian culture of the last third of the $18^{\text {th }}$ century the time of Ekaterina the second] (p. 71-90).

Filiushkin, A. I. (2008). Andrej Kurbskij [Andrei Kurbsky]. Moscow: Molodaya gvardiya.

Gerasimov, I. V., Glebov, S. V., Kaplunovskij, A. P., Mogil'ner, M. V. \& Semenov, A. M. (Eds.). (2004). Novaya imperskaya istoriya postsovetskogo prostranstva [New imperial history of the former Soviet Union]. Kazan.

Groh, D. (1988). Russland im Blick Europas. 300 Jahre historische Perspektiven. 2. Aufl. Frankfurt.

Hausmann, G. (1998). Universität und städtische Gesellschaft in Odessa: 1865-1917. Soziale und nationale Selbstorganisation an der Peripherie des Zarenreiches. Stuttgart.

Heller, W. (1990). Kooperation oder Konfrontation. M. V. Lomonosov und die russische Wissenschaft im 18. Jahrhundert. Jahrbücher für Geschichte Osteuropas NF, 39, $1-24$.

Hildermeier, M. (1987). Das Privileg der Rückständigkeit. Anmerkungen zum Wandel einer Interpretationsfigur der neueren russischen Geschichte. Historische Zeitschrift, 244, 557-603.

Hildermeier, M. (2004). Traditionen der Aufklärung in der russischen Geschichte. In H. Duchhardt, C. Scharf (Eds.). Interdisziplinarität und Internationalität. Wege und Formen der Rezeption der französischen und der britischen Aufklärung in Deutschland und Russland im 18. Jahrhundert (p. 1-16). Mainz.

Hosking, G. (2000). Russland, 1552-1917. Nation oder Imperium? 1552-1917. Berlin.

Hughes, L. (1998). Russia in the Age of Peter the Great. New Haven.

Hughes, L. (2002). Peter the Great. A Biography. New Haven; London.

Kaelble, H. \& Schriewer, J. (Eds). (2003). Vergleich und Transfer. Komparatistik in den Sozial-, Geschichts- und Kulturwissenschaften. (p. 9-52). Frankfurt a. M.; New York.

Koval'chuk, V. M. (Ed.) (2003). Sankt Peterburg. 300 let istorii [St. Petersburg. 300 years of history]. St. Petersburg.

Kusber, J. (1997). Krieg und Revolution in Rußland 1904-1906. Das Militär im Verhältnis zu Wirtschaft, Autokratie und Gesellschaft. Stuttgart.

Kusber, J. (2008a). Individual, Subject and Empire: Toward a Discourse on Upbringing, Education and Schooling in the Time of Catherine II. Ab Imperio, 2, 125-156.

Kusber, J. (2008b). Katharina II., das Russländische Imperium und die Bildung seiner Untertanen. Jahrbücher für Geschichte Osteuropas, 56, 358-378.

Kusber, J. (2009). Kleine Geschichte St. Petersburgs. Regensburg.

Kusber, J. (2013). Die Kontinuität der Fremdheit. Russland als das andere in historischer Perspektive. Osteuropa, 63 (2-3), 257-268.

Kusber, J. (2013). Transfer i sravnenie: universitetskie soobshhestva Rossii i Germanii [Transfer and comparison: university communities of Russia and Germany]. In E. A. Vishlenkov, I. M. Savel'ev (Eds.). Soslovie russkih professorov: sozdateli statistov i smy'slov [Class of Russian professors: creators of crowd and meanings] (p. 191-211). Moscow.

Kusber, J., Gerasimov, I. \& Semyonov, A. (Eds.). (2009). Empire Speaks out? Languages of Rationalization and Self-Description in the Russian Empire. Leiden.

Lieven, D. Empire. (2000). The Russian Empire and Its Rivals. London.

Lindner, R. (2003). Im Reich der Zeichen. Osteuropäische Geschichte als Kulturgeschichte, Osteuropa, 12, 1757-1771.

Martin, A. (1997). Romantics M. Reformers, Reactionaries. Russian Conservative Thought in the Reign of Alexander I. DeKalb. 
Michels, G. B. (1999). At War with the Church: Religious Dissent in SeventeenthCentury Russia. Stanford: Stanford Univ. Press.

Miller, A. I. (Ed.). (2004). Rossijskaya imperiya v sravnitel'noj perspective: sb. st. [The Russian Empire in comparative perspective: collection of articles]. Moscow.

Miller, A. I. \& Rieber, A. J. (Eds.). (2004). Imperial Rule. Budapest; New York.

Nitsche, P. (1991). "Nicht an die Griechen glaube ich, sondern an Christus". Russen und Griechen im Selbstverständnis des Moskauer Staates an der Schwelle zur Neuzeit. Düsseldorf.

Okenfuss, M. J. (1995). The Rise and Fall of Latin Humanism in Early Modern Russia. Pagan Authors, Ukrainians, and the Resiliency of Muscovy. Leiden usw.

Osterhammel, J. (2001). Transnationale Gesellschaftsgeschichte: Erweiterung oder Alternative? Geschichte und Gesellschaft, 27, 464-479.

Ostrowski, D. (2006). The Growth of Muscovy. In P. Maureen (Ed.). The Cambridge History of Russia. From Early Rus to 1689. (Vol. 1) (p. 213-239). Cambridge.

Patel, K. K. (2004). Überlegungen zu einer transnationalen Geschichte. Berlin.

Paulmann, J. (1998). Internationaler Vergleich und interkultureller Transfer. Zwei Forschungsansätze zur europäischen Geschichte des 18. bis 20. Jahrhundert. Historische Zeitschrift, 267, 649-685.

Perepiska Ivana Groznogo s Andreem Kurbskim [Correspondence of Ivan the Great with Andrei Kurbsky]. (1993). Moscow.

Pietrow-Ennker, B. (Ed.). (2007). Kultur in der Geschichte Russlands. Räume, Medien, Identitäten, Lebenswelten. Göttingen.

Pipes, R. (Ed.). (1959). Karamzin N. M. Karamzin's Memoir on Ancient and Modern Russia. Cambridge, Mass.

Poe, M. T. (2000). A People Born to Slavery. Russia in Early Modern European Ethnography, 1476-1748. Ithaca etc.

Renner, A. (2002). Die Erforschung der Langsamkeit. Russische Geschichte des 18. Jahrhunderts aus transnationaler Sicht. Archiv für Sozialgeschichte, 42, 297-314.

Sach, M. (2006). ,...setzen Sie sich und erzählen Sie!” Russische Salonkultur und russische Salonnièren seit der Zeit Katharinas II. bis in die erste Hälfte des 19. Jahrhunderts. In B. Lundt (Ed.). Historische Geschlechterforschung (Historische Miteilungen der Ranke Gesellschaft, 19) (p. 83-104). Stuttgart.

Scharf, C. (1995). Katharina II., Deutschland und die Deutschen. Mainz.

Scheidegger, G. (1993). Perverses Abendland, barbarisches Russland. Begegnungen des 16. und 17. Jahrhunderts im Schatten kultureller Missverständnisse. Zürich.

Schierle, I. (2007). "For the Benefit and Glory of the Fatherland": The Concept of Otechestvo. In R. Bartlett, L.-C. Gabriela (Eds.). Eighteenth-Century Russia: Society, Culture, Economy. Papers from the VII International Conference of the Study Group on Eighteenth-Century Russia (Wittenberg 2004) (p. 283-295). Berlin.

Schierle, I. (2005/2006). ,Vom Nationalstolze“: Zur russischen Rezeption und Übersetzung der Nationalgeistdebatte im 18. Jahrhundert. Zeitschrift für slavische Philologie, 64 (1), 63-85.

Schlögel, K. (1988). Jenseits des Großen Oktober. Das Laboratorium der Moderne, Petersburg 1909-1921. Berlin.

Schlözer, A. L. (Transl.). (1769; 1970). Katharinä der Zweiten Kaiserin und Gesetzgeberin von Rußland. Instruction für die zu Verfertigung des Entwurfs zu einem neuen Gesetzbuche verordnete Commission. (Reprint). Riga und Mitau; Frankfurt a. M.

Schulze-Wessel, M. (2000). Städtische und ländliche Öffentlichkeit in Russßland 1848. Zeitschrift für Geschichtswissenschaft, 48 (4), 293-308.

Shangina, I. I. et al. (Ed.). (2002). Mnogonacional'ny'j Peterburg. Istoriya. Religiya. Narody' [Multinational Petersburg. History. Religion. Peoples]. (2002). St. Petersburg.

Shevchenko, M. M. (Ed.). (1997). Sergej Semenovich Uvarov. Russkie konservatory' [Sergey Semenovich Uvarov. Russian conservatives] (p. 97-135). Moscow.

Simon, G. (2003). Russland. Historische Selbstvergewisserung und historische Mythen. Geschichtsdeutungen im internationalen Vergleich (p. 61-74). München (= Zur Diskussion gestellt, 63).

Smith, D. (1999). Working the Rough Stone. Freemasonry and Society in Eighteenth Century Russia. DeKalb.

Sperling, W. (Ed.). (2008). Jenseits der Zarenmacht. Dimensionen des Politischen im Russischen Reich, 1800-1917. Frankfurt a M.; New York.

Stiess, C. [Stieff]. (1706). Relationen von dem gegenwärtigen Zustand des moskowitischen Reichs. Frankfurt usw. 
Stürickow, R. (1990). Reisen nach St. Petersburg. Die Darstellung St. Petersburgs in Reisebeschreibungen (1815-1861). Frankfurt a. m.

Sylvester, R. P. (2005). Tales of old Odessa: crime and civility in a city of thieves. DeKalb, Ill.

Trotzki, L. (1923). Die russische Revolution 1905. Berlin.

Vierhaus, R. (1995). Die Rekonstruktion historischer Lebenswelten. Probleme moderner Kulturgeschichtsschreibung. In L. Hartmut (Ed.). Wege zu einer neuen Kulturgeschichte (p. 7-25). Göttingen.

Werner, M. \& Zimmermann, B. (2002). Vergleich, Transfer, Verflechtung. Der Ansatz der Histoire croisée und die Herausforderung des Transnationalen. Geschichte und Gesellschaft, 28, 607-636.

Werner, M. \& Zimmermann, B. (2006). Beyond Comparison. Histoire Croisée and the Challenge of Reflexivity. History and Theory, 45, 30-50.

Whittaker, C. H. (1978). The Ideology of Sergei Uvarov: An Interpretive Essay. Russian Review, 37, 158-176.

Zorin, A. L. (1996). Sergej Semenovich Uvarov. Ideologiya "Pravoslavie - samoderzhavie - narodnost"' i ee nemeczkie istochniki [Sergey Semenovich Uvarov. Ideology "Orthodoxy - autocracy - nationality" and its German origin]. In E. L. Rady'nskaya (Ed.). V razdum'yah o Rossii (XIX v.) [Thinking of Russia $\left(19^{\text {th }}\right.$ c.)] (p. 105-128). Moscow.

The article was submitted on 30.04.2014

\section{Ян Кусбер}

профессор истории Восточной

Европы, Германия

Майнцский университет Иоганна

Гутенберга

kusber@uni-mainz.de
Jan Kusber

Professor of East European

History, Germany

Johannes Gutenberg University

of Mainz

kusber@uni-mainz.de 